Table 1 Agonistic and antagonistic activities of some analogues of arginine-vasopressin

\begin{tabular}{|c|c|c|c|c|c|}
\hline \multirow{2}{*}{\multicolumn{2}{|c|}{ Analogue }} & \multicolumn{2}{|c|}{$\begin{array}{l}\text { Agonistic activities } \\
\text { (units } \mathrm{mg}^{-1} \text { ) }\end{array}$} & \multicolumn{2}{|c|}{$\begin{array}{l}\text { Antagonistic activities } \\
\text { effective dose }\left(\mathrm{nmol} \mathrm{kg}^{-1}\right)\end{array}$} \\
\hline & & Antidiuretic & Vasopressor & Antidiuretic & Vasopressor \\
\hline & AVP (ref. 1) & $330 \pm 23$ & $382 \pm 5$ & - & - \\
\hline & AVP-acid* & $4.7 \pm 0.6$ & $<0.3$ & - & - \\
\hline & desGly ${ }^{9}$ AVP $\dagger$ & $164 \pm 4$ & $<0.05 \S$ & - & $60 \pm 16$ \\
\hline & $\operatorname{desGly}^{9}\left(\mathrm{NH}_{2}\right)$ AVP $\ddagger$ & $5.6 \pm 1.1$ & $\sim 0.02 \S$ & - & - \\
\hline 1 & $\mathrm{~d}\left(\mathrm{CH}_{2}\right)_{5} \mathrm{AVP}$ (ref. 2) & $0.03 \pm 0.01$ & - & - & $0.56 \pm 0.11$ \\
\hline $1 a$ & desGly $-\mathrm{d}\left(\mathrm{CH}_{2}\right)_{5} \mathrm{AVP} \dagger$ & $\sim 0.003 \S$ & - & - & $0.28 \pm 0.04$ \\
\hline $1 b$ & $\operatorname{desGly}\left(\mathrm{NH}_{2}\right)^{9}-\mathrm{d}\left(\mathrm{CH}_{2}\right)_{5} \mathrm{AVP} \dagger$ & $0.04 \pm 0.01$ & - & - & $0.73 \pm 0.07$ \\
\hline 2 & $\mathrm{~d}\left(\mathrm{CH}_{2}\right)_{5}\left[\mathrm{D}-\mathrm{Phe}^{2}\right]$ VAVP (ref. 6) & Weak§ & - & $0.67 \pm 0.13$ & $0.58 \pm 0.04$ \\
\hline $2 a$ & desGly $-\mathrm{d}\left(\mathrm{CH}_{2}\right)_{5}\left[\mathrm{D}-\mathrm{Phe}^{2}\right]$ VAVP $\dagger$ & - & - & $0.58 \pm 0.11$ & $0.47 \pm 0.04$ \\
\hline $2 b$ & $\operatorname{desGly}\left(\mathrm{NH}_{2}\right)^{9}-\mathrm{d}\left(\mathrm{CH}_{2}\right)_{5}\left[\mathrm{D}-\mathrm{Phe}^{2}\right]$ VAVP $\dagger$ & - & - & $1.30 \pm 0.35$ & $0.80 \pm 0.08$ \\
\hline 3 & $\mathrm{~d}\left(\mathrm{CH}_{2}\right)_{5}[\mathrm{Tyr}(\mathrm{Et})]^{2} \mathrm{VAVP}($ refs 3-4) & $\sim 0.03 \S$ & - & $1.9 \pm 0.2$ & $0.49 \pm 0.11$ \\
\hline $3 a$ & desGly-d $\left(\mathrm{CH}_{2}\right)_{5}\left[\mathrm{Tyr}(\mathrm{Et})^{2}\right]$ VAVP $\dagger$ & - & - & $1.0 \pm 0.2$ & $0.45 \pm 0.02$ \\
\hline 4 & $\mathrm{~d}\left(\mathrm{CH}_{2}\right)_{5}\left[\mathrm{D}-\mathrm{Tyr}(\mathrm{Et})^{2}\right]$ VAVP (ref. 5) & Weak $\S$ & - & $1.1 \pm 0.2$ & $0.45 \pm 0.11$ \\
\hline $4 a$ & desGly-d $\left(\mathrm{CH}_{2}\right)_{5}\left[\mathrm{D}-\mathrm{Tyr}(\mathrm{Et})^{2}\right]$ VAVP $\dagger$ & - & - & $1.8 \pm 0.3$ & $0.45 \pm 0.04$ \\
\hline 5 & $'\left(\mathrm{CH}_{2}\right)_{5}\left[\mathrm{D}-\mathrm{Phe}^{2}, \mathrm{Ile}^{4}\right] \mathrm{AVP}$ (ref. 7) & - & - & $0.46 \pm 0.07$ & $0.99 \pm 0.12$ \\
\hline $5 a$ & desGly $-\mathrm{d}\left(\mathrm{CH}_{2}\right)_{5}\left[\mathrm{D}-\mathrm{Phe}^{2}, \mathrm{Ile}^{4}\right] \mathrm{AVP} \dagger$ & - & - & $0.66 \pm 0.17$ & $1.0 \pm 0.1$ \\
\hline
\end{tabular}

Except for AVP-acid, which was purchased from Bachem, all AVP analogues were synthesized in our laboratories by standard methods of peptide synthesis either in solution or by the Merrifield solid-phase method ${ }^{18}$, as previously described ${ }^{2-7}$. Details of these syntheses will be reported elsewhere.

* This analogue was originally reported to be an antidiuretic antagonist in vitro and in vivo ${ }^{13}$, but is shown here to be an antidiuretic agonist in vivo.

$\dagger$ This publication.

$\ddagger$ Originally obtained by tryptic cleavage of $\mathrm{AVP}^{10}$, pharmacological properties reported here for the first time.

$\S$ These analogues showed weak partial agonistic activity in these assays which was inconsistent and not clearly related to dose. Abbreviations: $\mathrm{AVP}$, arginine-vasopressin; AVP-acid, deamidoarginine vasopressin or vasopressinoic acid; $\mathrm{d}\left(\mathrm{CH}_{2}\right)_{5} \mathrm{AVP},[1$ - $(\beta$-mercapto, $\beta, \beta$-cyclopentamethylenepropionic acid)]arginine-vasopressin; $\mathrm{d}\left(\mathrm{CH}_{2}\right)_{5}\left[\mathrm{Tyr}(\mathrm{Et})^{2}\right] \mathrm{VAVP}, \quad[1-\beta$-mercapto- $\beta, \beta$-cyclopentamethylenepropionic acid),2-o-ethyltyrosine, 4-valine]arginine-vasopressin; $\quad \mathrm{d}\left(\mathrm{CH}_{2}\right)_{5}\left[\mathrm{D}-\mathrm{Tyr}(\mathrm{Et})^{2}\right]$ VAVP, $\quad[1-(\beta$-mercapto- $\beta, \beta$-cyclopentamethylenepropionic acid $), 2$-D- $(o$-ethyl)tyrosine, 4-valine]arginine-vasopressin; $\mathrm{d}\left(\mathrm{CH}_{2}\right)_{5}\left[\mathrm{D}-\mathrm{Phe}{ }^{2}\right]$ VAVP, $[1-(\beta$-mercapto- $\beta, \beta$-cyclopentamethylenepropionic acid $), 2$-D-phenylalanine, 4 -valine $]$ arginine-vasopressin; $\mathrm{d}\left(\mathrm{CH}_{2}\right)_{5}\left[\mathrm{D}-\mathrm{Phe}^{2}\right.$,Ile $\left.{ }^{4}\right] \mathrm{AVP},[1-(\beta$-mercapto- $\beta, \beta$-cyclopentamethylenepropionic acid $), 2$ - $\mathrm{D}$-phenylalanine, 4-isoleucine $]$ argininevasopressin (carboxy terminus is $\operatorname{Arg}\left(\mathrm{NH}_{2}\right)$; desGly, desglycine; desGly $\left(\mathrm{NH}_{2}\right)$, desglycinamide (carboxy terminus is $\operatorname{Arg}(\mathrm{OH})$ ).

Radiolabelled, photoaffinity or immunogenic covalent ligands of AVP receptor antagonists have not been developed to date. Such ligands could be useful tools for probing the structural characteristics and binding specificities of AVP receptors, isoreceptors and for the production of AVP anti-idiotypic antibodies. The desglycinamide modification of AVP receptor antagonists presents a novel and simple pathway for the synthesis of such ligands; by chemical or enzymatic coupling, in solution or on a solid support of a desglycinamide analogue via its carboxy-terminal $\mathrm{COOH}$ group to the amino group of an appropriately radiolabelled amino acid, photoaffinity derivatives or of suitable haptens.

Based on the data presented here for the AVP antagonists and on the finding that the Gly at position 9 in $d\left(\mathrm{CH}_{2}\right)_{5}\left[\mathrm{D}-\mathrm{Phe}^{2}\right.$, $\left.\mathrm{Ile}^{4}\right]$ AVP (ref. 7) can be replaced by L- or D-Ala, Ser or Arg, with retention of antagonism (unpublished), it is clear that position 9 can be either deleted or substituted with a variety of other derivatives with retention of potent antagonism. This opens up the possibility of incorporating modifications at this position which might lead to more potent and/or more selective antagonists for use as pharmacological tools in studies on the physiological, pathophysiological and behavioural roles of AVP and for potential clinical use.

We thank Ms Beverley Cifelli and Ms Donna Freshour for their help in manuscript preparation. This work was supported in part by research grants from the National Institute of General Medical Sciences (GM25280) and the National Institute of Arthritis, Diabetes, and Digestive and Renal Diseases (AM01940). The following authors are visiting investigators; A.O. from the Technical University of Lodz, Poland; W.K. and E.N. from the University of Wroclaw, Poland; A.K. from the Technical University of Gdansk, Poland; and A.M. from the University of Warsaw, Poland.

Received 2 November 1983; accepted 11 January 1984.

1. Sawyer, W. H., Grzonka, Z. \& Manning, M. Molec. cell. Endocr. 22, 117-134 (1981). 2. Kruszynski, M. et al. J. med. Chem. 25, 364-368 (1980).

3. Sawyer, W. H. et al. Science 212, 49-51 (1981)

4. Manning, M., Lammek, B., Kolodziejczyk, A. M., Seto, J. \& Sawyer, W. H. J. med. Chem 24, 701-706 (1981)
5. Manning, M. et al. J. med. Chem. 25, 45-50 (1982(a))

6. Manning, M., Klis, W. A., Olma, A., Seto, J. \& Sawyer, W. H. J. med. Chem. 25, 414-419 (1982).

7. Manning, M., Olma, A., Klis, W. A., Seto, J. \& Sawyer, W. H. J. med. Chem. 26, 1607-1613 (1983).

8. Reid, I.A. \& Schwartz, J. in Frontiers in Neuroendocrinology Vol. 8 (eds Martini, L. \& Ganong. W. F.) 177-197 (Raven, New York, 1984).

9. Manning, M. \& Sawyer, W. H. Trends Neurosci. 7, 6-9 (1984)

10. du Vigneaud, V., Lawler, H. C. \& Popenoe, E. A. J. Am. chem. Soc. 75, 4880-4881 (1953).

11. Kovacs, G. L. \& de Wied, D. Neuroendocrinology 37, 258-261 (1983).

12. Burbach, J. P. H., Kovacs, G. L., de Wied, D., van Nispen, J. W. \& Greven, H. M. Science 221, 1310 (1983).

13. Dousa, T., Hechter, O., Walter, R. \& Schwartz, I. L. Science 167, 1134-1135 (1970).

14. Sawyer, W. H. Endocrinology 63, 694-698 (1958).

15. Dekanski, J. Br. $J$. Pharmac. 7 ,

16. Dyckes, D. F., Nestor, J. J. Jr, Ferger, M. F. \& du Vigneaud, V. J. med. Chem. 17, 250-252 (1974).

17. Schild, H. O. Br. J. Pharmac. chem. Ther. 2, 189-206 (1947).

18. Barany, G. \& Merrifield, R. B. in The Peptides Vol. 2 (eds Gross, E. \& Meienhofer, J.) 1-284 (Academic, New York, 1979).

\section{Release of the predicted calcitonin gene-related peptide from cultured rat trigeminal ganglion cells}

\author{
R. Tom Mason, Robert A. Peterfreund, \\ Paul E. Sawchenko*, Anne Z. Corrigan, \\ Jean E. Rivier \& Wylie W. Vale
}

Peptide Biology Laboratory and *Developmental Neurobiology Laboratory, The Salk Institute, 10010 North Torrey Pines Road, La Jolla, California 92037, USA

Calcitonin gene-related peptide (CGRP) is a putative novel neuropeptide predicted on the basis of alternative RNA processing events of primary transcripts of the calcitonin gene ${ }^{1}$. Distinct mRNAs encoding either calcitonin or CGRP are generated from the calcitonin gene RNA transcript in what appears to be a tissue-specific manner ${ }^{1,2}$. The predicted peptide has now been detected immunocytochemically in discrete regions of the central and peripheral nervous systems ${ }^{2}$ and potent in vivo 
actions have been reported for centrally and peripherally administered synthetic CGRP ${ }^{3}$. However, so far there is no evidence that CGRP is secreted or released by intact cells. The present experiments investigated the possible secretion of CGRP in vitro using primary dispersed cell cultures of the adult rat trigeminal ganglion, which previously has been found to contain large amounts of CGRP mRNA (ref. 2). We report here that immunoreactive CGRP is spontaneously released by cultured trigeminal ganglion cells and that secretion is stimulated by incubation in high potassium medium in a calciumdependent fashion. Chromatographic characterization of the secreted CGRP-like immunoreactivity (CGRP-LI) isolated only one molecular form which appears to be similar or identical to the predicted rat CGRP (1-37).

Trigeminal ganglia were obtained from adult male SpragueDawley rats (Holtzman, 200-220 g) and enzymatically digested into dispersed cells using a method previously described ${ }^{4,5}$ (see Fig. 2 legend for details). At the time of a secretion experiment, all cells appeared healthy and well differentiated. Figure 1 shows a fluorescence photomicrograph of a cultured trigeminal ganglion cell stained using an antiserum against a synthetic analogue of CGRP, [ $\left.\mathrm{Tyr}^{23}\right] \mathrm{CGRP}(23-37)$. In culture dishes prepared as described in Fig. 1 legend, a small percentage $(<1 \%)$ of cells were reliably stained using a conventional indirect immunofluorescence method ${ }^{6}$. Cells stained for CGRP-LI were typically medium in size, measuring $18-22 \mu \mathrm{m}$ in diameter, round or polygonal in shape, and gave rise to 4-7 processes that branched extensively in the area immediately surrounding the cell body. Cells stained in culture for CGRP-LI were thus similar in size and shape to trigeminal ganglion cells stained in $s^{2} u^{2}$, although extensive local plexuses of neuronal processes comparable to those described here could not be resolved in sections through intact ganglia.

Basal release of CGRP-LI from trigeminal ganglion cells in dispersed culture was readily measurable using our radioimmunoassay. Typically, $10-30 \mathrm{fmol}$ of CGRP-LI were released per dish during a 60-min incubation period. Depolarization of cells by incubation for $60 \mathrm{~min}$ in high potassium $(59 \mathrm{mM})$ medium typically elicited the release of 90-250 fmol of CGRPLI per dish ( $~ 30 \%$ of total cellular content of CGRP-LI), a 7-11-fold increase over basal levels. When calcium ion was removed from the high potassium medium, the release of

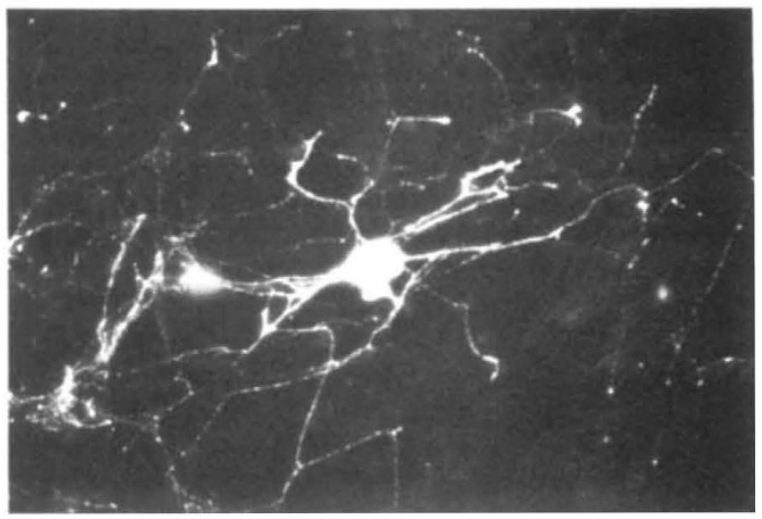

Fig. 1 Fluorescence photomicrograph of a cultured trigeminal ganglion cell. After 4-6 days in culture, dishes $(n=25$, from different preparations over a period of 2 months) were fixed for $15 \mathrm{~min}$ in $4 \%$ paraformaldehyde and $0.5 \%$ glutaraldehyde in borate buffer at $\mathrm{pH} 9.5$. Indirect fluorescence histochemistry was then done as described in detail elsewhere ${ }^{6}$, using an antiserum raised against a synthetic analogue of CGRP, $\left[\mathrm{Tyr}^{23}\right] \mathrm{CGRP}(23-37)$, conjugated to human $\alpha$-globulin and used at a dilution of $1: 2,000$. This serum was preabsorbed with human $\alpha$-globulin $\left(7.5 \mu \mathrm{g} \mathrm{ml}^{-1}\right)$. Each of the stained processes shown in the photomicrograph could be traced to the cell body at the centre. Staining of trigeminal ganglion cells was completely blocked by the addition of synthetic $\left[\mathrm{Tyr}^{23}\right]$ CGRP(23-37) or CGRP(1-37) $\left(1 \mathrm{mg} \mathrm{ml}^{-1}\right)$; addition of synthetic substance $P$, somatostatin(1-14), or human calcitonin at the same concentration did not influence staining.

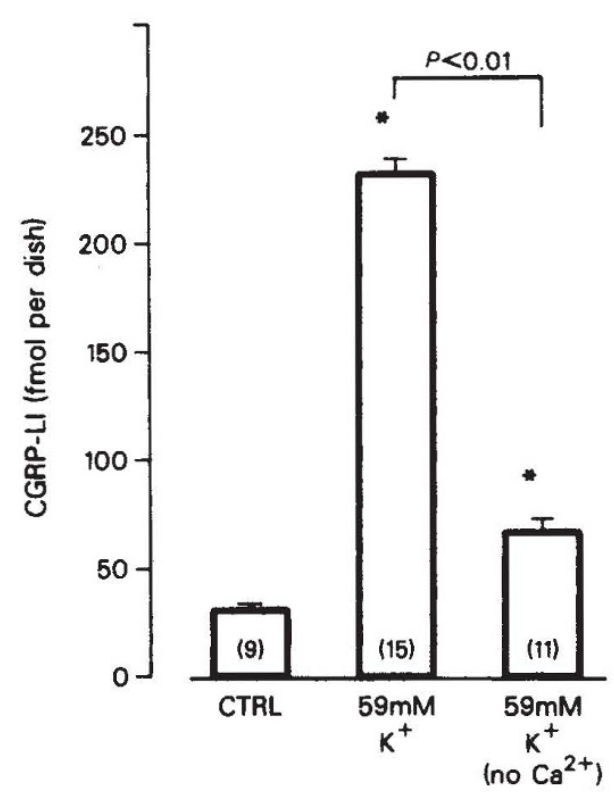

Fig. 2 Basal (CTRL) and stimulated $\left(59 \mathrm{mM} \mathrm{K}^{+}\right)$release of CGRP-like immunoreactivity (CGRP-LI) from trigeminal ganglion cells in primary dispersed cell culture. The calcium $\left(\mathrm{Ca}^{2+}\right)$ dependency of the $59 \mathrm{mM} \mathrm{K}^{+}$-induced release of CGRP-LI is also shown $\left(59 \mathrm{mM} \mathrm{K}^{+}\right.$, no $\mathrm{Ca}^{2+}$ ).

Methods: One hundred pairs of trigeminal ganglia were collected and dissociated enzymatically for $150 \mathrm{~min}$ in sterile siliconized spinner flasks using collagenase II (Worthington) $)^{4,5}$. DNAase II $\left(3.2 \times 10^{3}\right.$ Kunitz units; Sigma) was added at 40,95 and $130 \mathrm{~min}$. Following dispersion of the tissue, cells were washed, resuspended in HEPES-buffered Dulbecco's modified Eagle's medium (HDMEM) containing $10 \%$ fetal calf serum (FCS) and plated at a density of $5 \times 10^{6}$ cells per $60 \mathrm{~mm}$ tissue culture dish (Falcon 3002 , previously coated with poly-D-lysine at $20 \mu \mathrm{g} \mathrm{ml}^{-1}$ ) this is equivalent to four trigeminal ganglia per dish. The culture medium was changed 3 days after plating to HDMEM + $5 \%$ FCS and secretion experiments were performed the following day. On the day of an experiment the culture medium was aspirated off the dishes and the cells were washed three times with $2.0 \mathrm{ml}$ HEPES-Krebs-Ringer's-bicarbonate glucose solution $(\text { HKRBG })^{4}$. Cells were then equilibrated in $1.0 \mathrm{ml}$ HKRBG for $1 \mathrm{~h}$, followed by a $1 \mathrm{~h}$ experimental period in HKRBG with or without $59 \mathrm{mM} \mathrm{K}^{+}$. Finally, cells were exposed to high $\mathrm{K}^{+}(59 \mathrm{mM})$ HKRBG for $1 \mathrm{~h}$ to validate responsiveness. Appearance of cells following a secretion experiment was unremarkable. At the end of each incubation, the media were collected and placed in glass tubes at $4{ }^{\circ} \mathrm{C}$, heated for $5 \mathrm{~min}$ at $90^{\circ} \mathrm{C}$, chilled and assayed within $12 \mathrm{~h}$ for CGRP-LI. Synthetic CGRP(1-37) and a C-terminal analogue, [Tyr $\left.{ }^{23}\right]$ CGRP(23-37), were prepared on a $p$-methylbenzhydrylamine resin as described previously ${ }^{7}$ and purified using preparative scale reverse-phase HPLC $^{8}$. Peptide purity was $>95 \%$ as determined by amino acid analysis and analytical reverse-phase HPLC. Antisera were raised in New Zealand rabbits to a synthetic C-terminal analogue of CGRP, which was first coupled to human $\alpha$-globulin via glutaraldehyde. The final dilution of antiserum was 1 : 85,000-100,000. Radiolabelled ligand $\left(\left[{ }^{125} I-T_{y r}{ }^{23}\right] C G R P(23-\right.$ 37)) was prepared by the chloramine-T method and purified by reverse-phase HPLC on a Vydac C-18 column. Standard curves were constructed using CGRP(1-37). Antibody complexes were precipitated with Pansorbin (Staphylococcus aureus protein A; Calbiochem). The minimum detectable dose was 2-4 pg CGRP(137 ) per assay tube and the $50 \%$ effective dose $\left(E D_{50}\right)$ of the radioimmunoassay standard curve was in the range $45-55 \mathrm{pg}$ CGRP(1-37). None of the media used in our cell culture system or any of the peptides tested exhibited any cross-reactivity in the radioimmunoassay. Statistical comparisons (multiple range tests of Dunnett and Duncan) analysed the responses of dishes to test substances or control (HKRBG) during the experimental period. Numbers in parentheses indicate the number of dishes per treatment group. ${ }^{*} P<0.01$. 


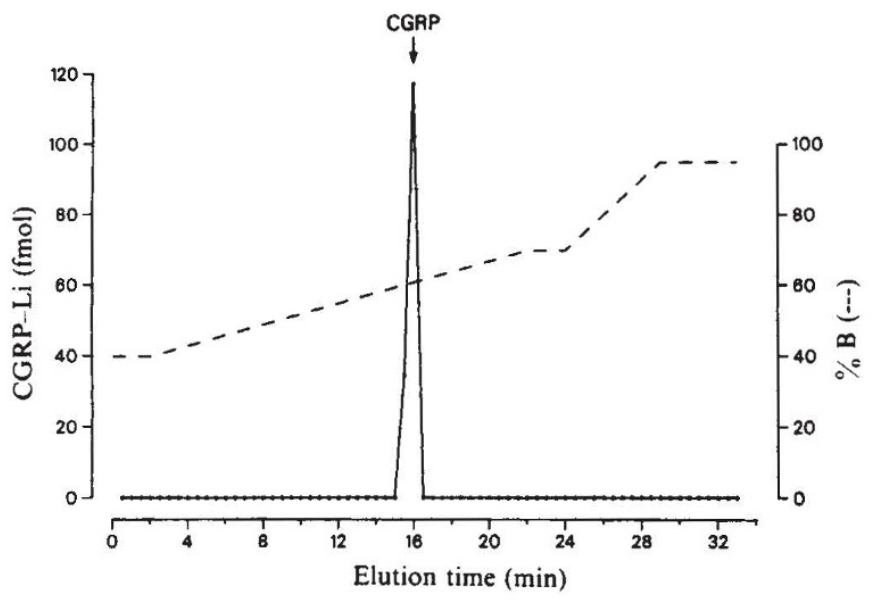

Fig. 3 Reverse-phase HPLC of pooled gel filtration chromatography samples taken from the zone containing $>90 \%$ of the recoverable CGRP-LI (see text). Solvents for reverse-phase HPLC were $0.1 \%$ trifluoroacetic acid (TFA) in deionized water (solution A) and $0.1 \%$ TFA in a mixture of $60 \%$ acetonitrile $/ 40 \%$ deionized water (solution B). Lyophilized sample or synthetic CGRP(1-37) was dissolved in $1.5 \mathrm{ml}$ of solution $\mathrm{A}$ and $0.5-1.5 \mathrm{ml}$ was applied to a Vydac C-18 column $(0.46 \times 25 \mathrm{~cm}$, particle size $5 \mu \mathrm{m}$, pore size $330 \AA$ ). Chromatograms were run for $33 \mathrm{~min}$ at $20-25^{\circ} \mathrm{C}$ in conditions of increasing amounts of solution $\mathrm{B}$ (see diagram) using an Altex gradient liquid chromatograph Model 332. Flow rate was $1.5 \mathrm{ml} \mathrm{min}-1$ and fractions were collected every $0.5 \mathrm{~min}$ into glass tubes containing $5 \mu \mathrm{l}$ of $10 \%$ bovine serum albumin (BSA) in $\mathrm{H}_{2} \mathrm{O}$. Fractions were lyophilized, reconstituted in assay buffer, neutralized with $2 \mathrm{M}$ sodium hydroxide and assayed for CGRP-LI. Blank runs of injections of solution A were performed before each application of sample or synthetic CGRP(1-37). No CGRP-LI was detected in any of these collected fractions. Recovery of CGRP-LI from samples or synthetic CGRP(1-37) across the HPLC column was $\sim 70 \%$. When basal or $59 \mathrm{mM} \mathrm{K}^{+}$medium was taken directly for reverse-phase HPLC, using a Vydac or a Waters C-18 column $(0.46 \times 30 \mathrm{~cm}$, particle size $10 \mu \mathrm{m}$, pore size $120 \AA)$, the media from 50 or 25 dishes was first pooled into an equal volume of $2 \mathrm{M}$ acetic acid at $4{ }^{\circ} \mathrm{C}$ containing $12.5 \mathrm{mM}$ EDTA. The acidified medium was then heated at $90^{\circ} \mathrm{C}$ for $5 \mathrm{~min}$, cooled to $4^{\circ} \mathrm{C}$ and then partially purified over Bond Elut (Analytichem) disposable C-18 cartridges to remove large $(>20,000$ molecular weight) proteins. Samples were then prepared and applied to the columns as described above. The arrow on the diagram indicates the elution time of synthetic rat CGRP(1-37).

CGRP-LI was attenuated (Fig. 2). Secretion of CGRP-LI by cultured trigeminal ganglion cells resembles calcium-dependent, high potassium-induced secretion of other peptides in different in vitro model systems ${ }^{4,5}$. Returning cells that had been stimulated with $59 \mathrm{mM}$ potassium to culture medium for 18-24 h and repeating the experiment the next day demonstrated that cells could typically release significant amounts $(70-100 \%)$ of CGRP-LI compared with the previous day.

Gel filtration chromatography of CGRP-LI released from trigeminal ganglion cell cultures depolarized with $59 \mathrm{mM}$ potassium medium demonstrated that more than $90 \%$ of the total CGRP-LI recovered from the column eluted in the $K_{\mathrm{d}}$ range $0.28-0.41$, with the peak at a $K_{\mathrm{d}}$ of 0.33 . Synthetic CGRP(1-37) applied to the same column eluted in an almost identical manner (>90\% CGRP-LI in $K_{\mathrm{d}}$ range $0.33-0.42, K_{\mathrm{d}}$ peak at 0.38 ). In both cases only one peak of immunoreactivity was observed. No calcitonin-like immunoreactivity was detected in the column eluant or in media from cells depolarized with $59 \mathrm{mM}$ potassium. In other experiments, we combined the fractions containing the CGRP-LI peak from gel filtration of medium from high potassium-stimulated cells. The pooled lyophilisate was then subjected to reverse-phase HPLC and only one peak of CGRP-LI was observed, which co-eluted with synthetic CGRP(1-37) (Fig. 3). Media from unstimulated (basal) and stimulated (59 mM potassium) cultured cells were also directly subjected to reverse-phase HPLC (following the procedures outlined in Fig. 3) and an identical profile was observed. Together, these data provide strong evidence that only one molecular form of CGRP-LI is released from our cultured trigeminal ganglion cells and that this is very similar, if not identical, to synthetic rat CGRP(1-37).

In summary, our data provide the first direct evidence of secretion of CGRP-LI from nervous tissue and support the possibility that CGRP may have a role as an extracellular modulator. Secretion appears to depend on the availability of extracellular calcium, as is expected in secretory systems of established physiological significance. Only one molecular form of CGRP-LI, apparently identical to the predicted rat CGRP(137 ), is released. Our observations agree with a previous report describing high levels of CGRP immunoreactivity and CGRP mRNA in trigeminal ganglia ${ }^{2}$ and with studies suggesting a tissue specificity in the generation of mRNAs encoding calcitonin or CGRP $^{1,2}$. Furthermore, the data support the possibility that alternative RNA processing mechanisms are a biologically significant means of increasing the diversity of extracellular regulatory molecules.

This research was supported by NIH grant AM-26741 and a grant from The Keck Foundation. This research was conducted in part by the Clayton Foundation-California Division. P.E.S. and W.W.V. are Clayton Foundation Investigators. R.T.M. is a University of Melbourne Research Fellow. R.A.P. is the recipient of a Medical Scientist Training Program Award PHS GM07198. The support, advice and assistance of Drs T. Bruhn, H. Seifert, M. G. Rosenfeld, R. Evans, L. Swanson, L. Bilezikjian and M. Chen, and M. Boyle, D. Chin and R. McClintock are gratefully appreciated.

Received 14 November 1983; accepted 1 February 1984

1. Amara, S. G., Jonas, V., Rosenfeld, M. G., Ong, E. S. \& Evans, R. M. Nature 298, 240-244 (1982).

2. Rosenfeld, M. G. et al Nature 304, 129-135 (1983).

3. Fisher, L. A. et al. Nature 305, 534-536 (1983).

4. Peterfreund, R. A. \& Vale, W. W. Brain Res. 239, 463-477 (1982).

5. Shoemaker, W. J., Peterfreund, R. A. \& Vale, W. W. Meth. Enzym. 103, 347-362 (1983)

6. Sawchenko, P. E. \& Swanson, L. W. Brain Res. 210, 31-51 (1981).

7. Marki, W., Spiess, J., Tache, Y., Brown, M. \& Rivier, J. E. J. Am. chem. Soc. 103, 3178-3185 (1981).

8. Rivier, J., McClintock, R., Galyean, R. \& Anderson, H. J. Chromatogr. (in the press).

\section{Rivier, J., McClintock, R., Galyean, R. \& Anderson, H. J. Chromarogr. (in the press).}

\section{Recombinant nontoxinogenic Vibrio cholerae strains as attenuated cholera vaccine candidates}

\section{James B. Kaper, Hank Lockman, Mary M. Baldini \& Myron M. Levine}

Center for Vaccine Development, University of Maryland School of Medicine, 10 South Pine Street, Baltimore, Maryland 21201, USA

An ideal vacine does not yet exist to prevent cholera, a significant health problem in many less developed countries. Vibrio cholerae, the agent of epidemic and endemic cholera, colonizes the small bowel and secretes a potent enterotoxin that consists of a single A subunit, which stimulates adenylate cyclase activity, and five identical B subunits which bind to the ganglioside $\mathbf{G M}_{\mathbf{1}}$ receptor of intestinal mucosal cells $\mathbf{1}^{\mathbf{1}}$. Previous studies in man indicate that toxoid-derived antitoxic immunity by itself is insufficient to provide effective, long-lasting protection against cholera ${ }^{2-4}$. Using recombinant DNA techniques we have now constructed a live, attenuated $V$. cholerae strain by deleting genes encoding the enterotoxin. Restriction enzyme fragments encoding cholera toxin were deleted in vitro from cloned vibrio chromosomal DNA and the resulting mutations introduced into the chromosome of a vibrio strain of proven immunogenicity. Recently, Mekalanos and coworkers ${ }^{5}$ have reported attenuated V. cholerae strains constructed by similar methods. It appears that recombinant DNA techniques offer a promising approach to the development of effective cholera vaccines.

Experimental cholera studies in community volunteers at the Center for Vaccine Development, University of Maryland, have 